\title{
Aberrant nerve fibres within the spinal cord
}

\author{
J. TREVOR HUGHES AND BETTY BROWNELL
}

\author{
From the Departments of Pathology and Neurology, The Radcliffe Infirmary, Oxford
}

Raymond (1893), in a necropsy account of a case of syringomyelia, described in the wall of the syrinx small bundles of fine nerve fibres ensheathed with Schwann cells. He traced the origin of these fibres from the posterior root entry zone and decided that they arose from axons of the cell bodies in the posterior root ganglia. Similar findings in syringomyelia were subsequently recorded by Schlesinger (1902), Bischofswerder (1901), Jonesco-Sisesti (1929), and Druckman and Mair (1953). Similar bundles of nerve fibres within and around the spinal cord have been described in other disease processes: in tabes dorsalis by Nageotte (1899), in Pott's paraplegia by Fickler (1900), in malignant cord compression by Bielschowsky (1901) and by Druckman and Mair (1953), in traumatic cord lesions by Henneberg (1907), by Roussy and Lhermitte (1918), and by Klaue (1949), in multiple sclerosis by Berchenko (1935), and in cervical spondylosis by Mair and Druckman (1953). These references do not exhaust the world literature, and further instances are given in a review of the subject undertaken by Druckman (1955) for a symposium on regeneration in the central nervous system, held at Bethesda, Maryland, in 1954. Most of these quoted references refer to single instances of this phenomenon which appears to be rare although its exact incidence cannot be stated. In the present paper we record our own observations on the occurrence of these abnormal nerve fibres, illustrated by nine personally studied examples.

The principal clinical features and neuropathological findings are given in the Table. In the account that follows we have confined our observations to the detailed microscopical studies of the aberrant nerve fibres.

DESCRIPTION OF ABBERANT NERVE FIBRES STUDIED

EXAMPLE 1 The spinal cord contained a syrinx extending from $\mathrm{C} 4$ to $\mathrm{L} 1$ and placed asymmetrically transversely across the posterior half of the cord. At C6 (Fig. 1) the syrinx, extending transversely across the cord, affecter the left posterior horn and interrupted fibres from then left C6 posterior nerve root. In this region, within connective tissue forming the posterior wall of the synrinx, were small irregular bundles of fine nerve fibres, myelinated and ensheathed with Schwann cells (Fig. 2)?

TABLE

SUMMARY OF CLINICAL FEATURES

\begin{tabular}{|c|c|c|c|c|c|c|c|}
\hline \multicolumn{2}{|c|}{ Case No. } & \multicolumn{2}{|c|}{$\begin{array}{l}\text { Sex and } \\
\text { Age }\end{array}$} & \multirow{2}{*}{$\begin{array}{l}\text { Diagnosis } \\
\text { Syringomyelia }\end{array}$} & \multirow{2}{*}{$\begin{array}{l}\text { Duration of } \\
\text { Neurological } \\
\text { Symptoms }\end{array}$} & \multirow{2}{*}{$\begin{array}{l}\text { Neuropathological Findings } \\
\text { Syrinx from C4 to L1 asym- } \\
\text { metrically placed across posterior } \\
\text { half of cord }\end{array}$} & \multirow{2}{*}{$\begin{array}{l}\text { Position of Aberrant } \\
\text { Axons }\end{array}$} \\
\hline 1 & C.G. & $\mathbf{M}$ & 60 & & & & \\
\hline 2 & D.G. & $\mathbf{M}$ & 37 & Necrotizing myelitis & $14 \mathrm{yr}$. & $\begin{array}{l}\text { Complete destruction of cord below } \\
\text { T7 }\end{array}$ & T8 to conus replacing cord \\
\hline 3 & W.B. & $\mathbf{M}$ & 28 & $\begin{array}{l}\text { Necrotizing myelitis and } \\
\text { multiple sclerosis }\end{array}$ & $10 \mathrm{yr}$. & $\begin{array}{l}\text { Multiple sclerosis plaques in brain; } \\
\text { total destruction of cord below T8 }\end{array}$ & I 8 to conus replacing cord \\
\hline 4 & W.S. & $\mathbf{M}$ & 59 & $\begin{array}{l}\text { Spinal injury with cord } \\
\text { transection }\end{array}$ & $16 \mathrm{yr}$. & $\begin{array}{l}\text { Connective tissue scar replacing } \\
\text { destroyed cord at } \mathrm{T} 10, \mathrm{~T} 11 \text {, and } \\
\mathrm{T} 12\end{array}$ & $\begin{array}{l}\text { T10 to } \mathrm{T} 12 \text { in connective } \\
\text { tissue scar }\end{array}$ \\
\hline 5 & M.S. & $\mathbf{F}$ & 35 & Neuromyelitis optica & $11 \mathrm{yr}$. & $\begin{array}{l}\text { Atrophy with gliosis of optic } \\
\text { nerves and spinal cord }\end{array}$ & $\begin{array}{l}\text { Cervical and upper thoracic } \\
\text { cord, in posterior columns }\end{array}$ \\
\hline 6 & G.H. & $\mathbf{M}$ & 61 & Acute anterior poliomyelitis & $40 \mathrm{yr}$. & $\begin{array}{l}\text { Atrophy of anterior horns and } \\
\text { anterior roots }\end{array}$ & $\mathbf{T} 7$, in grey commissure \\
\hline 7 & F.L. & $\mathbf{M}$ & 76 & Secondary carcinoma of spine & 9 mth. & $\begin{array}{l}\text { Infarction of spinal cord from } \\
\text { T1 to T7 due to tumour infiltra- } \\
\text { tion of spine }\end{array}$ & T6 in grey commissure \\
\hline 8 & G.P. & $\mathbf{F}$ & 62 & Cervical spondylosis & 8 yr. & $\begin{array}{l}\text { Spondylosis associated with C5-6 } \\
\text { and C6-7 discs, causing cord } \\
\text { ischaemia }\end{array}$ & $\begin{array}{l}\text { C6 in right anterior white } \\
\text { column }\end{array}$ \\
\hline 9 & G.B. & $\mathbf{F}$ & 70 & $\begin{array}{l}\text { Diabetes mellitus and } \\
\text { schizophrenia }\end{array}$ & Not known & Atrophy of posterior nerve roots & $\begin{array}{l}\text { T6 in grey commissure } \\
\text { and anterior median sulcus }\end{array}$ \\
\hline
\end{tabular}




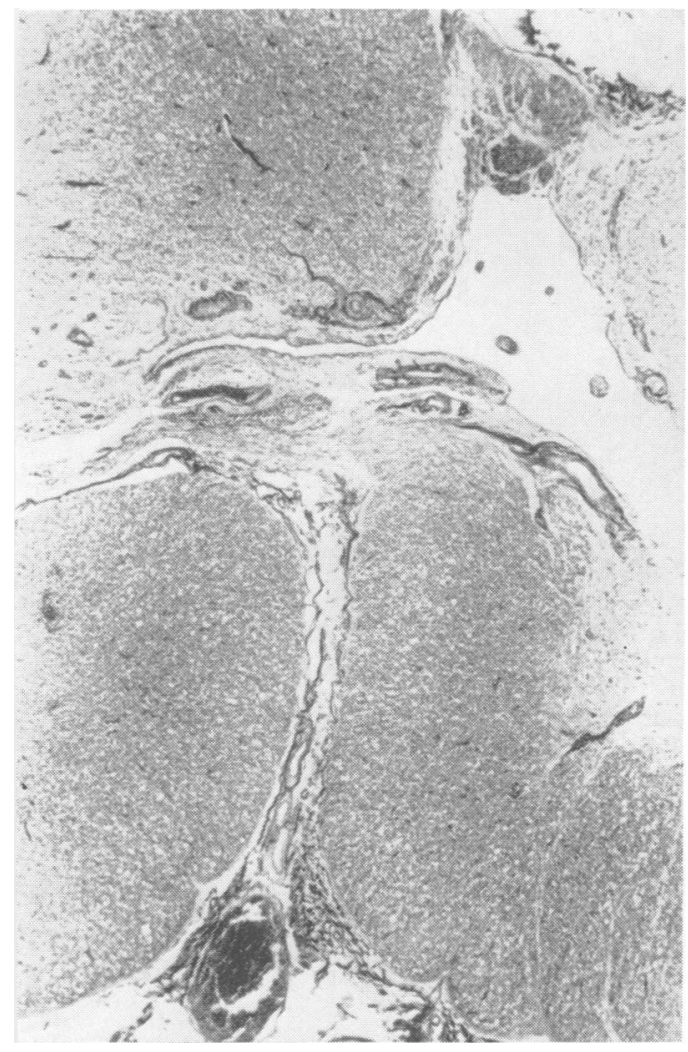

IG. 1. Case 1. Transverse section of C6 spinal cord egment showing an irregular syrinx cavity with a undle of abnormal nerve fibres in its posterior wall. Haematoxylin and Van Gieson $\times 27$.

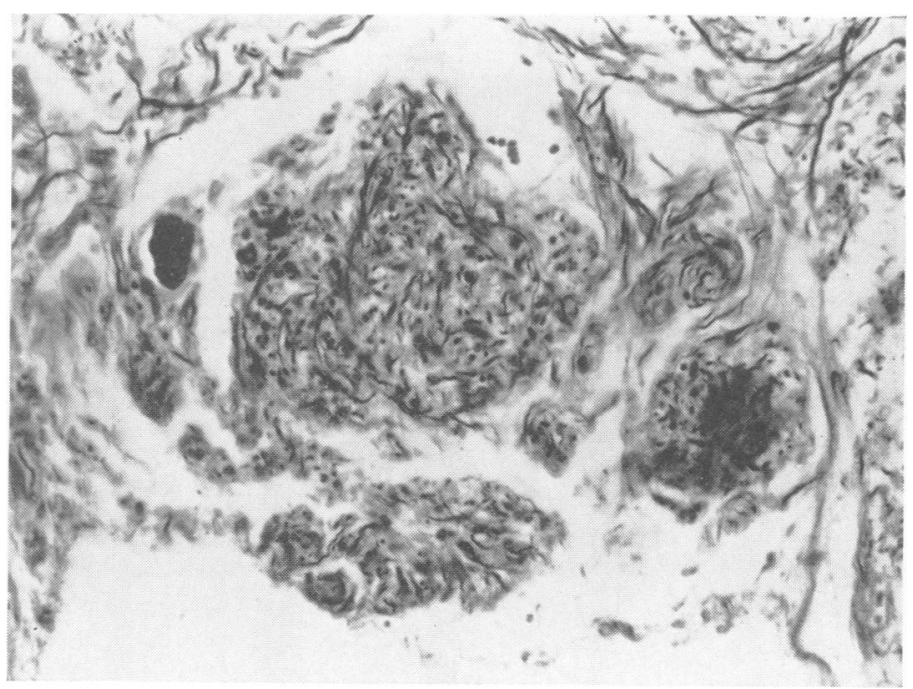

FIG. 2

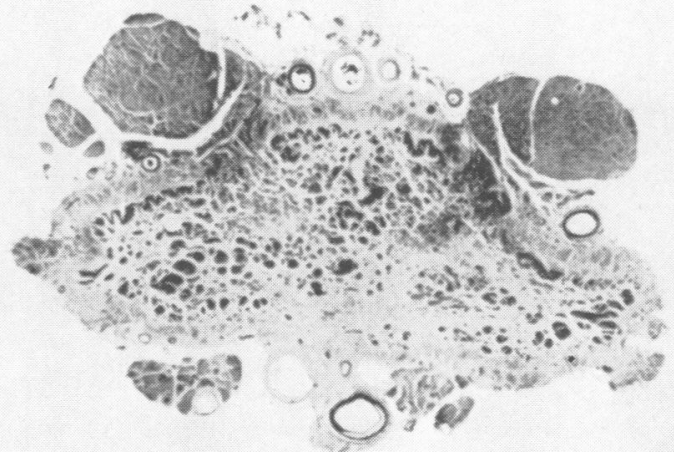

FIG. 3
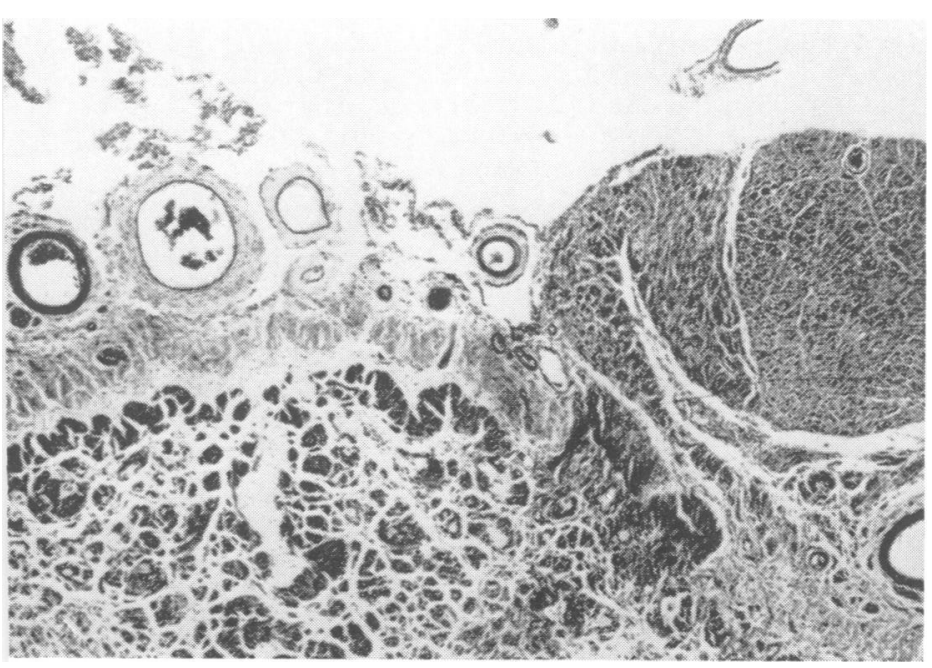

FIG. 2. Case 1. High-power magnification of Fig. 1 showing the abnormal bundle to consist of irregular, intertwined axons. (Holmes $\times 255$.

FIG. 3. Case 2. Transverse section at LI stained for myelin. No normal spinal cord remains, instead there are bundles of interlacing myelinated fibres cut in transverse section. Note the plump posterior nerve roots in contrast to the atrophied anterior nerve roots. $($ Weil $\times 12$.)

FIG. 4. Case 2. Transverse section at LI stained for myelin and showing $a$ posterior root from which fibres are entering the spinal cord and joining the abnormal bundles. $($ Weil $\times 35$.) 


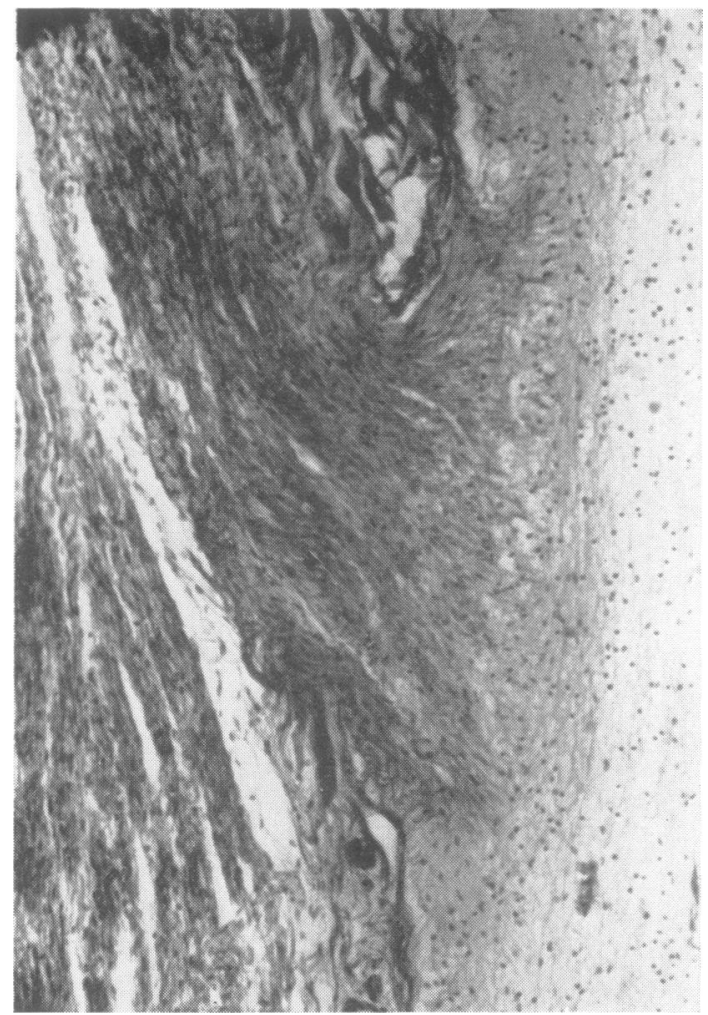

FIG. 5

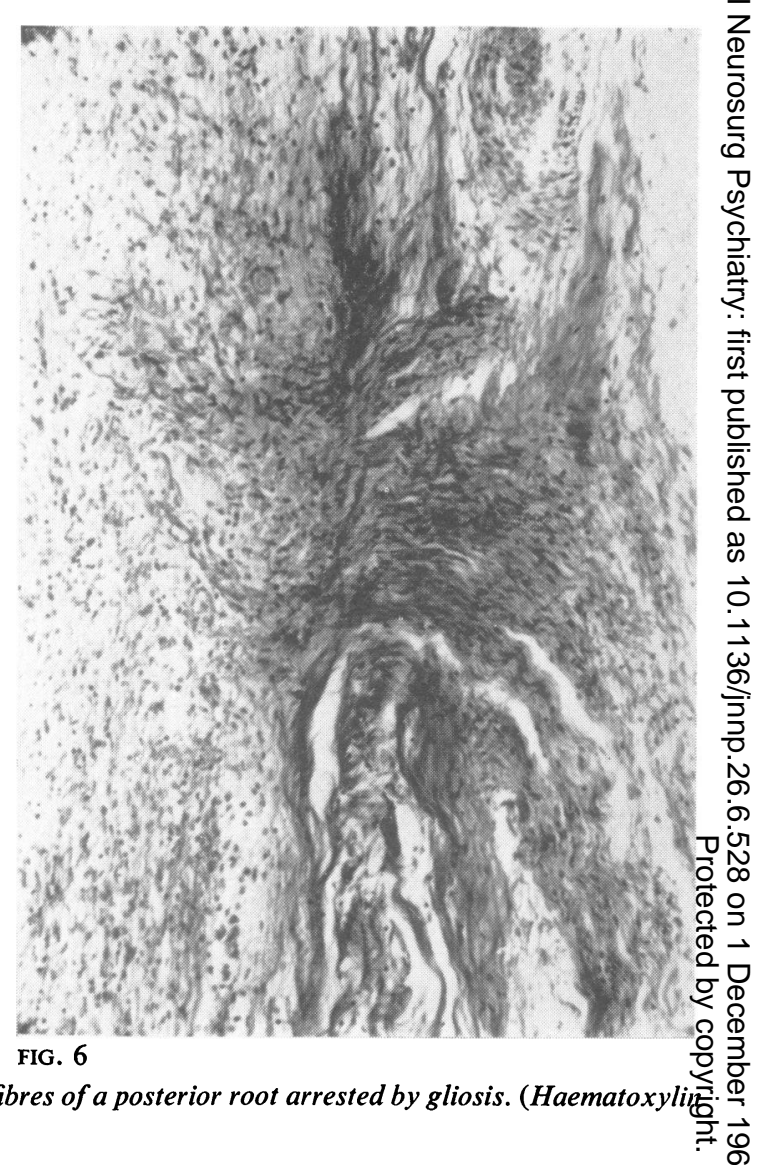

के

FIG. 6. Case 4. View from same section as Fig. 5 but showing fibres of a posterior root growing into adjacent connective tissue scar. (Haematoxylin and Van Gieson $\times 102$.)

Serial sections demonstrated their close association with the posterior root entry zone. Every spinal cord segment was sectioned but no further abnormal fibres were found.

EXAMPLE 2 This case and case 3 have been described in detail elsewhere (Hughes, 1961).

The spinal cord was normal down to T6 segment below which normal nervous tissue was totally destroyed.

The spinal cord below T7 was completely replaced by interlacing bundles of peripheral type nerve fibres mainly arranged parallel to the longitudinal axis of the spinal cord (Fig. 3). In a detailed microscopic study the origin of these nerve fibres from the posterior nerve roots was demonstrated (Fig. 4). Analysis of this and other cases showed that in this necrotic form of myelitis, neurones, nerve fibres, and glia were completely destroyed. The final sequel was invasion of the region of cord necrosis by nerve fibres regenerating from neurones in the posterior root ganglia.

EXAMPLE 3 The spinal cord was atrophied below T8 having suffered almost total destruction of normal nervous tissue. The destroyed region of the spinal cord was replaced by large numbers of peripheral type nerve fibres in the form of irregular bundles. As in case 2 , their origin from the intact posterior nerve roots could be demonstrated.

EXAMPLE 4 The spinal cord at segments T10, T11, and T12 was severely damaged, being replaced by a thick connective tissue scar enveloping the meninges. Longitudinal sections through cord segments T10, T11, and T12 showed a scar of connective tissue merging above and below into gliosis. Throughout the connective tissue scar were tangled nerve fibres of peripheral type, ramifying widely but never entering a region of gliosis. The origin of these abnormal fibres from the posterior nerve roots could frequently be demonstrated (Fig. 6).

EXAMPLE 5 The spinal cord showed extensive atrophy with gliosis suggestive of an antecedent destructive process destroying grey and white matter. Bundles of peripheral type nerve fibres were present in the posterior columns on the right side near the posterior root entry zone. These were seen in many sections from the cervical 


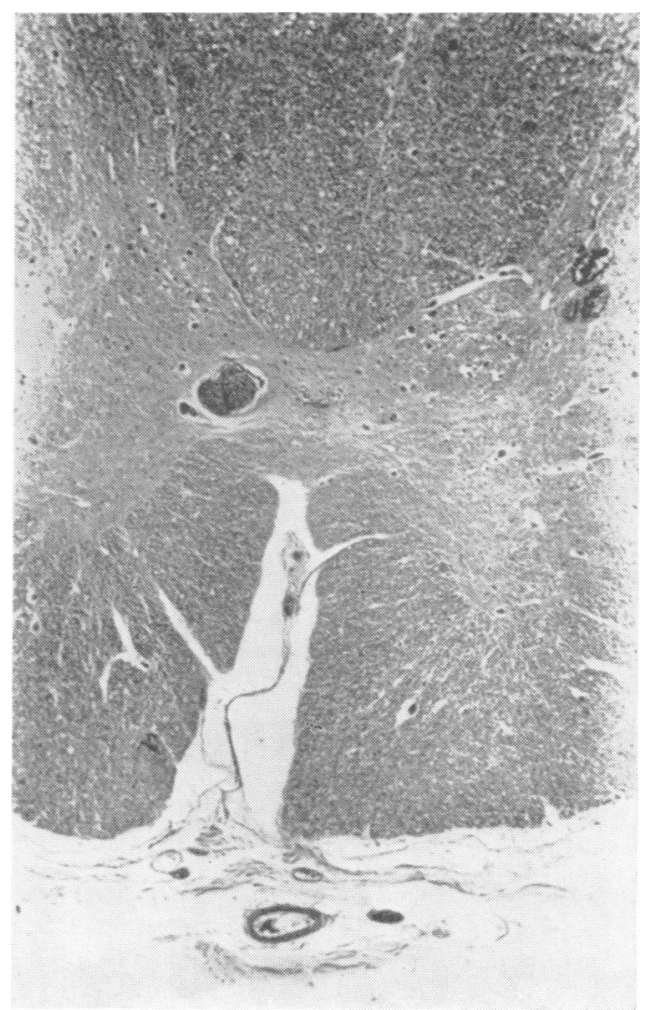

FIG. 7

and upper thoracic cord segments where they formed an abnormal bundle seen in the posterior columns. In some sections fibres were demonstrated joining the bundle from nearby posterior nerve roots.

These five examples may be conveniently considered together, for they are similar in that in each case the spinal cord was invaded by abnormal fibres arising from the posterior or nerve roots.

The common factor was long survival after a destructive process involving the region of posterior nerve root entry (in cases 1 and 5) or the whole cross-section of the cord (in cases 2, 3, and 4). In case 1 the position of the abnormal fibres suggested strongly that they arose from posterior nerve roots. This origin was quite certain in cases $2,3,4$, and 5 since nerve fibres could be followed in serial histological sections from the plump healthy posterior nerve roots into the spinal cord to join the interlacing bundles of abnormal fibres. In cases 2,3 , and 4 there was no possibility of proliferation from other cell bodies or axons, for these had perished in the severe and total spinal cord necrosis.

In the next three instances the pathology was different as was the location of the aberrant fibres.

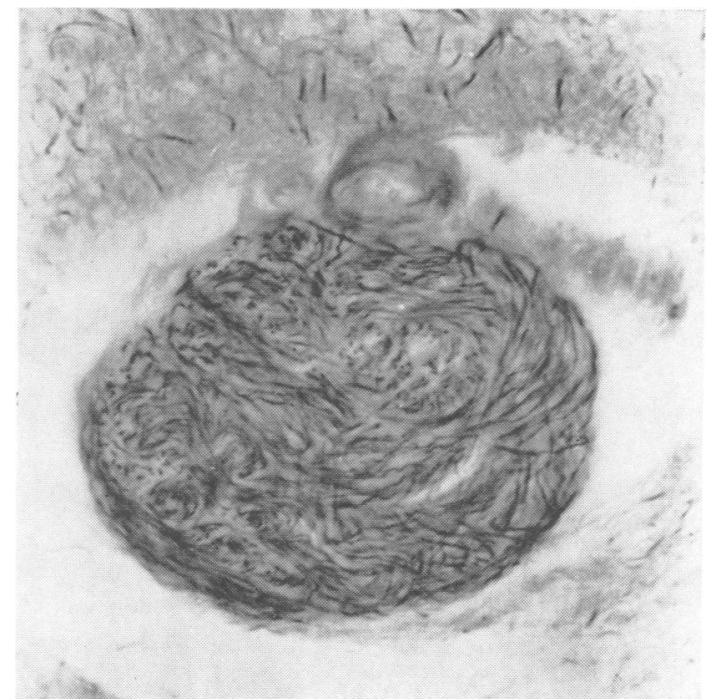

FIG. 8 .

FIG. 7. Case 6. Transverse section of spinal cord at T7 segment showing position of abnormal fibres in the grey commissure. The anterior horns show atrophy with neuronal loss. (Haematoxylin and Van Gieson $\times 27$.)

FIG. 8. Case 6. High-power view of Fig. 7 showing the appearance of the bundle when stained for nerve axons. (Holmes $\times 255$. $)$

EXAMPLE 6 The spinal cord showed in its thoracic and lumbar regions atrophy of the anterior nerve roots and neuronal depletion with gliosis in the anterior horns. In the $\mathrm{T} 7$ spinal cord segment a small spherical bundle of intertwined fine myelinated nerve fibres was situated in a perivascular space in the grey commissure on the right side (Figs. 7 and 8). Serial sections demonstrated the shape, size, and extent of these abnormal nerve fibres but failed to show their origin. From their position they were presumed to arise from cell bodies in the right anterior horn.

EXAMPLE 7 The spinal cord from $\mathrm{T} 1$ to $\mathrm{T} 7 \mathrm{had}$ suffered infarction from extensive infiltration of the spine by tumour. Tumour was present in the extradural space but had not invaded the spinal canal or its leptomeninges.

In T6 spinal cord segment a small bundle of peripheral type nerve fibres (myelinated and associated with Schwann-cell nuclei) was present in the grey commissure on the right side. The bundle, composed of intertwined fine axons, was surrounded by a thin layer of spongy connective tissue, the whole structure being within a perivascular space. Serial sections demonstrated the extent and the spherical shape of the bundle but failed to show its origin. The neighbouring anterior and lateral grey horns were severely depleted of neurones by the neoplastic process. 


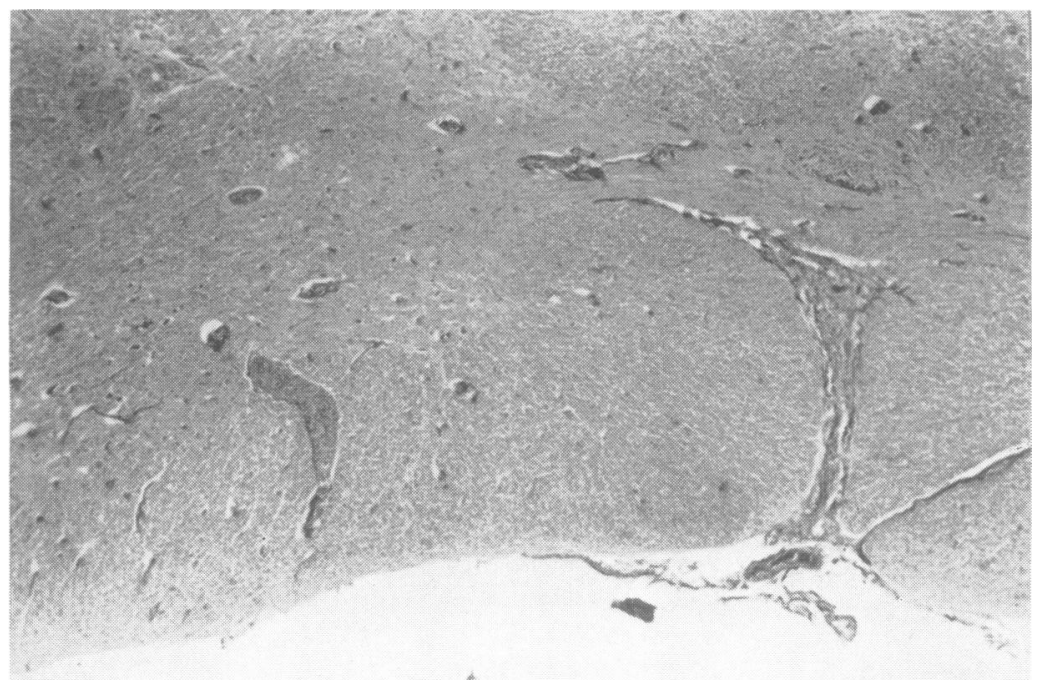

FIG. 9. Case 8. Low-power view of right anterior part of $\mathcal{D}$ transverse section through C6 spinal cord segment. The abnormal fibres are situated in a perivascular space in the right anterior white column.

(Haematoxylin and Van Gieson $\times$ 27.)

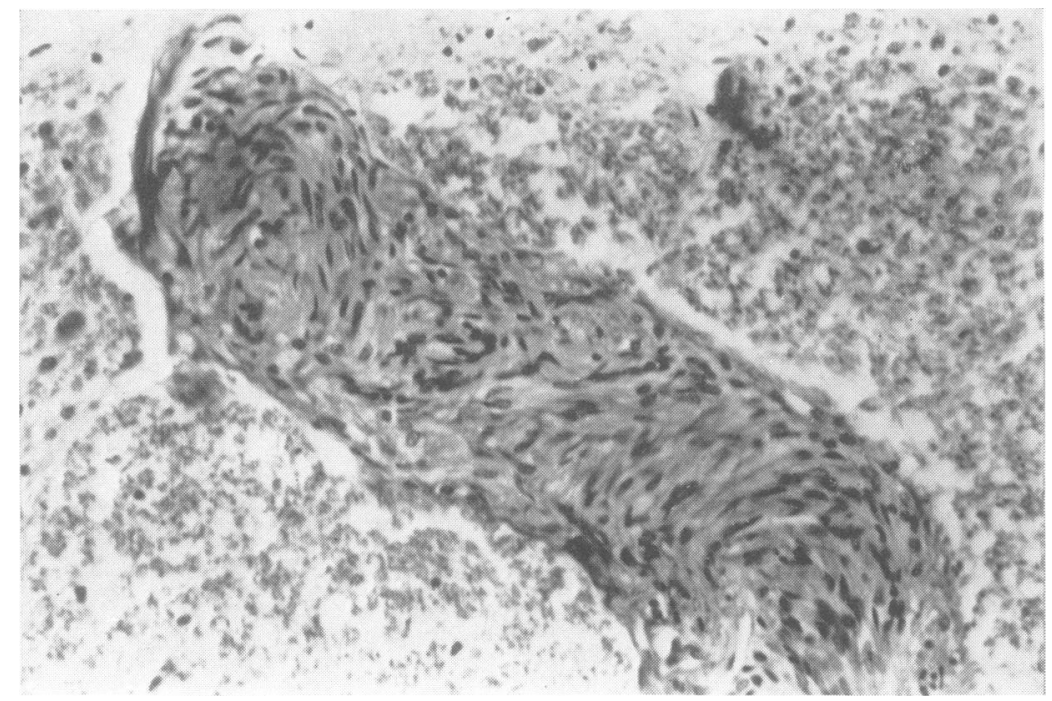

FIG. 10. Case 8. Highpower view of abnormal fibres seen in Figure 9. (Haematoxylin and Van Gieson $\times 255$.)

EXAMPLE 8 Severe spondylosis affected the cervical spine with protrusions associated with $\mathrm{C} 5$ to $\mathrm{C} 6$ and $\mathrm{C} 6$ to $\mathrm{C7}$ discs bulging backwards into the spinal canal and indenting the spinal cord. The spinal cord showed myelin and neuronal loss from $\mathrm{C} 6$ to $\mathrm{C} 8$ with vascular proliferation suggestive of ischaemia. Wallerian degeneration was evident above and below the affected segments. A fusiform bundle of fine myelinated peripheral type nerve fibres was present in C6 spinal cord segment within a radially situated perivascular space in the right anterior white column (Figs. 9 and 10). Serial sections demonstrated their extent and suggested, but did not prove, their origin from cell bodies in the right anterior horn.
The three cases just described were alike in having a disease affecting the anterior horn cells. In each a $\frac{0}{3}$ small bundle of abnormal nerve fibres was found in a perivascular space: in cases 6 and 7 in the grey commissure and in case 8 in the anterior white $₹$

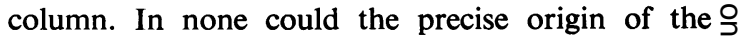
fibres be established but from their position the $D$ likeliest explanation was that they arose from cell 을 bodies in the anterior horn.

EXAMPLE 9 In T6 cord section small bundles of inter- $\mathbb{O}$ twined axons surrounded the vessels in the anterior 


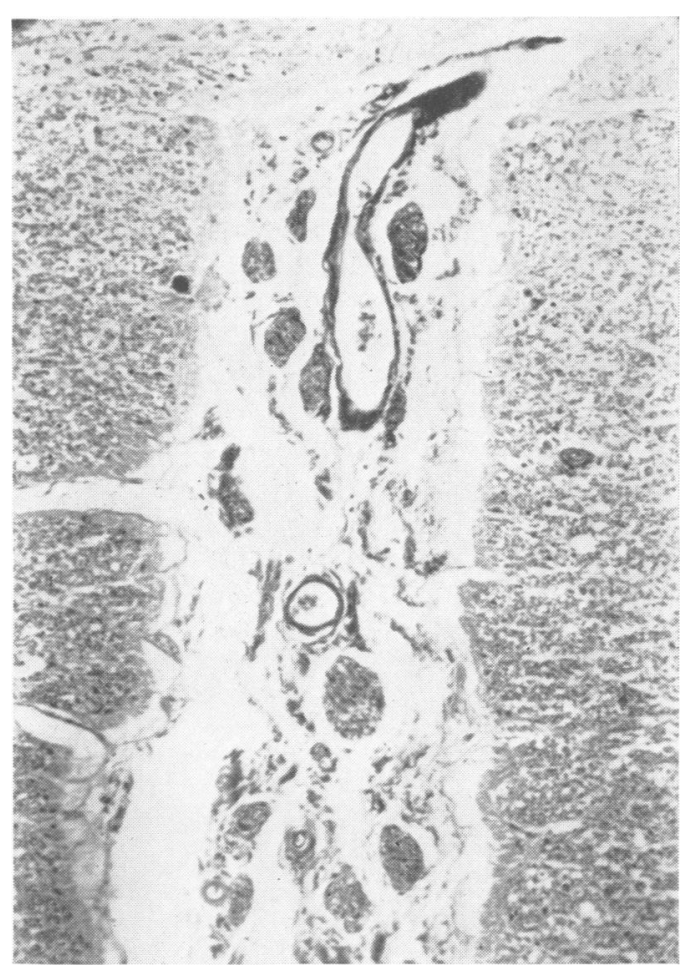

FIG. 11. Case 9. Transverse section of T6 spinal cord segment showing anterior median sulcus with many abnormal fibres around a sulcal artery. (Haematoxylin and Van Gieson $\times$ 102.)

median sulcus (Fig. 11) and were present in several perivascular spaces in the grey commissure on the left and in two spaces on the right. The appearances suggest ramifying nerve fibres entering the spinal cord alongside a sulcal branch of the anterior spinal artery. Similar bundles of abnormal fibres were seen in the leptomeninges on the lateral aspect of the cord and near one posterior nerve root.

In this last instance the findings differed from all the other cases in that the abnormal fibres were present in greatest numbers in the anterior median sulcus around a sulcal artery. Within the spinal cord they were present in much smaller numbers in two perivascular spaces in the grey commissure, one on either side of the central canal, these vessels being branches of the sulcal artery. These abnormal fibres had probably entered the spinal cord centripetally along the spinal vessels. Their exact origin could not be determined but the presence of similar fibres near one posterior nerve root and the clinical evidence of diabetes mellitus suggested the possibility of their arising from nerve roots damaged by a diabetic neuropathy.
DISCUSSION

The nature and origin of these abnormal nerve fibres has been the subject of recurrent speculation which is reviewed by Druckman and Mair (1953) with whose conclusions we are mainly in agreement. The suggestion that the fibres concerned are abnormally placed spinal nerve roots can be discounted, as their interlacing pattern is quite unlike the parallel fibres of a normal spinal nerve root. They are not normal perivascular nerves (as described and illustrated by Clark in 1929), for the aberrant fibres are present in much greater numbers and differ in always possessing myelin sheaths. That these bundles might be neurofibromata does not require extensive consideration, for the resemblance is quite superficial, and all the structures we have described in this paper can be demonstrated with silver stains to be composed of interwoven axons. We arrive at the most probable explanation that these aberrant nerve tangles are the result of proliferation of severed axons.

From our analysis of the cases it can be seen that we favour in six cases showing these abnormal fibres (cases 1, 2, 3, 4, 5, and 9) an origin in the cell bodies of the posterior spinal ganglia. In the other three cases we have suggested an origin in the anterior horn neurones. In none of our cases was there evidence for regeneration from long intraspinal nerve fibres, and so our findings do not support the contention (held by an important minority) that regeneration of this type of injured axon occurs within the spinal cord.

The nerve fibre bundles we have described are more akin to neuromata occurring after peripheral nerve or spinal root section. That they occur within the spinal cord seems to us less important than the observation that in other respects they are similar to traumatic neuromata. Severed posterior root axons have a propensity to regenerate as we have recently observed in necropsy studies in a case of posterior rhizotomy for intractable pain. The regenerating nerve fibres were identical histologically with those we describe here though ramifying only in the leptomeninges and not entering the intact spinal cord. One pertinent observation common to all our cases is that the immediate environment of the abnormal nerve fibres, even though technically within the spinal cord, is not central nervous tissue but mesodermal connective tissue. This relationship was most evident in case 4 where a traumatic connective tissue scar replaced large areas of the spinal cord. The mesodermal scar was everywhere invaded by peripheral type fibres which never entered nearby areas of normal or gliosed central nervous tissue. It seems that these fibres, for some interesting and 
hitherto unexplained reason, are not usually able to grow into central nervous tissue. This observation has a parallel in animal experiments, such as those of Windle, Clemente, and Chambers (1952). These workers embedded the cut proximal end of the facial nerve of cats, rabbits, and rats into the animal's own brain. The interesting result was a connective tissue scar containing a large neuroma whose fibres failed to invade the neighbouring brain. The barrier to such invasion is not seemingly insuperable, for Windle et al., by treating their animals with piromen, A.C.T.H., or desoxycorticosterone, could persuade the proliferating fibre of the implanted nerve to spread into the adjacent brain tissue.

Concerning the function of these abnormal nerve fibres, it is clear that they serve no useful purpose. Cases 2, 3, and 4 had suffered a complete paraplegia with total interruption of all motor and sensory pathways. The invasion of the spinal cord by abnormal fibres of peripheral nerve type was very extensive, yet there was no evidence of any clinical improvement in their many years of paraplegic life.

\section{SUMMARY}

Nine instances are reported in which at necropsy irregular bundles of fine myelinated axons associated with Schwann-cell nuclei were found inside the spinal cord.

In six cases the nerve bundles appeared to arise from posterior nerve roots, this origin being clearly demonstrable in five cases. In three cases the spinal cord was replaced to a remarkable extent by these abnormal fibres, which could only have arisen from the posterior nerve roots. for all other cell bodies and axons had perished in the severe and total spinal cord necrosis. In three cases the position of the nerve bundles suggested their origin from cell bodies of anterior horn neurones.

The abnormal nerve fibres were always surrounded by mesodermal connective tissue, never by gliosis $\overline{\hat{\theta}}$ or normal central nervous tissue.

All the instances followed some destructive process, suggesting that the origin of the fibres was the proliferation of severed axons.

None of these cases provided evidence for regeneration from long intraspinal nerve fibres, for $\overline{\bar{v}}$ the nerve fibre bundles described could never be traced to this type of injured axon.

The observations recorded in this paper were made possible by the courtesy of the many people from whom we receive material for neuropathological examination.

For clinical details we thank Dr. W. Ritchie Russell $\rightarrow$ (cases 1, 5, and 8), Dr. Ludwig Gutman (cases 2, 3, and. 4), Dr. J. D. Kidd (case 6), Mr. J. Pennybacker (case 7), and Dr. Sabina Strich (case 9).

\section{REFERENCES}

Berchenko, F. (1935). Schweiz. Arch. Neurol. Psychiat., 37, 3. Bielschowsky, M. (1901). Neurol. Zbl., 20, 242.

Bischofswerder, L. (1901). Rev. neurol., 9, 178.

Clark, S. L. (1929). J. comp. Neurol., 48, 247.

Druckman, R. (1955). In Regeneration in the Central Nervous Svstem, edited by W. F. Windle, p. 241. Thomas, Springfield, Illings.

, and Mair, W. G. P. (1953). Brain, 76, 448.

Fickler, A. (1900). Dtsch. Z. Nervenheilk., 16, 1.

Henneberg, R. (1907). Charité-Ann., 31, 161.

Hughes, J. T. (1961). M.D. Thesis, University of Manchester

Jonesco-Sisesti, N. (1929). Tumeurs Médullaires Associées à Processus Syringomyélique. Masson, Paris.

Klaue, R. (1949). Wien. Z Nervenheilk., 2, 488.

Mair, W. G. P., and Druckman, R. (1953). Brain, 76, 70.

Nageotte, J. (1899). C.R. Soc. Biol. (Paris), 51, 738.

Raymond (1893). Arch. Neurol. (Paris), 26, 97.
Roussy, G., and Lhermitte, J. (1918). Les Blessures de la Moelle et deç la Queue de Cheval. Masson, Paris.

Schlesinger, H. (1902). Die Syringomyelie, 2nd ed. Deuticke, Leipzig and Vienna.

Windle, W. F., Clemente, C. D., and Chambers, W. W. (1952) J. comp. Neurol., 96, 359

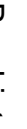

